\title{
Ezra Pound's Early Poetics and His Early Romantic and Imagist Poems
}

\author{
Wei Shu ${ }^{1}$ \\ ${ }^{1}$ School of Foreign Studies, Beijing Information Science and Technology University, Beijing, China \\ *Correspondence: School of Foreign Studies, Beijing Information Science and Technology University, Beijing, China. \\ E-mail: susiejournal@163.com
}

Received: April 30, 2014

Accepted: May 22, $2014 \quad$ Online Published: August 21, 2014

doi:10.5430/wjel.v4n3p18

URL: http://dx.doi.org/10.5430/wjel.v4n3p18

\begin{abstract}
This paper intends to study Ezra Pound's early poetics and his early Romantic and Imagist Poems. It studies firstly the poetic conception of Ezra Pound--“A Few Don'ts", trying to analyze the few important principles that Pound put forward in his early poetic conception, which set him apart from other poets before; then it comes to the discussion of his early Romantic and Imagist Poems.
\end{abstract}

Keywords: Ezra Pound; early poetics; Romantic and Imagist Poems

\section{Introduction}

The incubating process of Ezra Pound's poetics is very complicated. Pound absorbed the quintessence from different culture and literary tradition. The elements that have played vital role in the formation of his poetics range from the Provençal lyrical poems, the popular ballads, Browning's dramatic monologues, Yeatsian Symbolism, Old English poems, to the oriental influence, especially from Chinese classical poems. Pound adopted different poetic concepts and started to form his own poetics: the early translations and romantic lyrics of Pound and the new translation concepts and poetics in his "The Seafarer", demonstrate that part of the influence on his early poetics was from the western traditional cultural inheritance and that the emphasis on musicality that Pound inherited from traditional forms of poetry turns out to be one of the major principles that Pound advocates in his early poetics; Robert Browning's dramatic monologues and Yeats's Symbolism enabled Pound to transit from the poet of subjectivity to that of objectivity; Pound's understanding of oriental culture, especially of Chinese classical poems, played a major role in Pound's formation of imagist principles and modernist poetics. All these different cultural background and literature inheritance paved the way that Pound was going to follow in shaping his early poetics and his unique style and gradually led Pound into the grandiose palace of Modernism.

Pound knew less about French literature, which was very influential in the forming of his Imagism school, but he could more easily synthesize what he knew. He goes a long way to blend the essence of the previous fine literature and his own thoughts on true poetry. Therefore his poetics is inclusive and wide-ranged and he uses it as a weapon to fight against the out-of-date traditions and the banality in the works of the conservative.

\section{The Poetic Conception of Ezra Pound--“"A Few Don'ts"}

Pound's poetic conception was not formed overnight. He suffered a lot before his came to the final stage of his poetic idea. In 1912, Pound, Richard Aldington, and H.D. found they were agreed on three principles:

Direct treatment of the "thing" whether subjective or objective.

To use absolutely no word that does not contribute to the presentation.

As regards rhythm: to compose in the sequence of the musical phrase, not in the sequence of a metronome.

(Amdur 1936: 38)

These principles were printed in Poetry: A Magazine of Verse for March 1913, and were followed by “A Few Don'ts by an Imagiste" signed by Ezra Pound. This essay has been widely acknowledged as the declaration of Pound's 
poetics. The following "don'ts" can clarify the principles that Pound advocates in his school of Imagism:

Use no superfluous word, no adjective, which dose not reveal something.

Don't use such an expression as "dim lands of peace." It dulls the image...the natural object is always the adequate symbol.

Go in fear of abstractions.

Don't imagine that the art of poetry is any simpler than the art of music.

Let the candidate fill his mind with the finest cadences he can discover, preferably in a foreign language, so that the meaning of the words may be less likely to divert his attention from the movement.

It is not necessary that a poem should rely on its music, but if it does rely on its music that music must be such as will delight the expert.

Let the neophyte know assonance and alliteration, rhyme immediate and delayed, simple and polyphonic, as a musician would expect to know harmony and counterpoint and all the minutiae of his craft. No time is too great to give to these matters or to any one of them, even if the artist seldom have need of them.

In short, behave as a musician, a good musician, when dealing with that phrase of your craft which has exact parallels in music.

Consider the definiteness of Dante's presentation as compared with Milton's rhetoric. Read as much of Wordsworth as does not seem too unutterably dull.

If you want the gist of the matter go to Sappho, Catullus, Vilon, Heine when he is in the vein, Gautier when he is not too frigid; or, if you have not the tongues, seek out the leisurely Chaucer. Good prose will do you no harm, and there is good discipline to be had by trying to write it.

Translation is likewise good training.

If you are using a symmetrical form, don't put in what you have to say and then fill up the remaining vacuums with slush.

(Amdur 1936: 39)

Pound wants to wake up poets and hearers at once, both in England and America. His first opportunity came in America; Harriet Monroe had sensed the restlessness under the surface of America letters, and Poetry: A Magazine of Verse, established in October, 1912, gave an outlet to the new current. Pound appeared in the first issue, with a poem, "To Whistler, American" arraigning his country for its inhospitality to the arts. He was immediately named foreign correspondent of the magazine and from then on the Imagistes had an American public.

Many poets were under his influence, guidance and encouragement. Amy Lowell always insisted on Pound's ability to stimulate. "He could make you write," she would say. Within two years Amy Lowell, Robinson Jeffers, Edgar Lee Masters, Edna Millay, Sara Teasdale, and Vachel Lindsay published in America: aside from the thin and little-known volumes of E. A. Robinson it was the first crop of real poetry for two generations.

\section{The Significance of "A Few Don'ts"}

"A Few Don'ts" by Ezra Pound is a great achievement in modern poetry, since it opens a brand new era for modern poetry, which otherwise would have gone into a dead end. Like what he said, poets at that time "all ran about like puppies with ten tin cans tied to our tails." He with his revolutionary and imagist "don't" unfastened the burdens and the tins on the back and tail of the poets. Some of his "don'ts" in his remark are down to the earth yet very crucial for the composition of poems, while others are very innovative and revolutionary. The influence of Pound's imagist "don'ts" lasts for a long time and it indeed changes the trend and the style of the poetry of many generations.

Ezra Pound is a person who has done more for poetry than almost any of his contemporaries. Amdur writes in his dissertation: "he (Pound) entered the service of English letters when the grate was cold. He stirred up the embers of poetry and kindled a flame that has lasted twenty years" (1936: 90). This is exactly the honor that Ezra Pound should deserve for what he has done for modern poetry.

\section{A Comparison of the Poetic Conceptions between Pound and Other Poets}

Of course these maxims are the common-sense ones that almost all good poetry has always followed, and there is 
nothing new in them except the emphasis on music and perhaps the condemnation of Milton. But although they seem commonplace now, they were important, first, because Pound practiced them himself, and second, because they very definitely needed saying at the time. "Nineteen-twelve was a bad year," wrote Pound looking back from 1915, "we all ran about like puppies with ten tin cans tied to our tails. The tin cans of Swinburnina rhyming, of Browningisms, even...of Kiplingisms, a resonant pendant, magniloquent, Miltonic, sonorous."

These "don'ts" by Pound point out some problems existing commonly in the poems at the 1910's and before that period. Many writers mistakenly regard the form and rhetoric as the most important elements in composing a poem. Pound mentioned several poets in his remark: Swinburne, Browning, Kipling and Milton, because many writers tend to follow their method of rhyming, decoration, and rhetoric instead of focusing on the inner feeling and the heart of the poem. The few "don'ts" toll the bell for poets; otherwise they would be led astray by attaching great importance only to the form and the poetic devices.

Swinburne in his play and in the volume which followed it, Poems and Ballads (1866), demonstrated a metrical virtuosity that dazzled his early readers and is still dazzling. "Those who demand that poetry should make sense, first and foremost, may find that much of his poetry is not to their taste. What he offers, instead, are heady rhythmical patterns in which words are relished as much for their sound as for their sense" (Abrams 1986: 1540).

Browning also experienced some change in his writing. After The Ring and the Book, several volumes appeared. In general Browning's writing during the last two decades of his life suffer from "a certain mechanical repetition of mannerisms and an excess of argumentation" (Abrams 1986: 1232).

After Pound arrived in London, seeking "such as love this same beauty that I love somewhat after mine fashion", he found that W.B. Yeats had changed his style. What Yeats gave Pound was no longer the attitude and vocabulary but "the example of a poet with a vivid imagination who spent all his life striping off layers of rhetoric" (Amdur 1936: 21) which benefits Pound throughout his life.

Pound published some Provençale, French, and Italian poems under the title Personae. A certain group recognized their strange original quality instantly, and even the Daily News was enthusiastic. The new title, taken from the Latin, means "masks of the actor," and his use of it showed that Pound had already recognized his genre. The most important of the new poems join the class initiated by "Cino", which used the monologue to present a character and a situation. Though some of the poems descended from Browning's Men and Women, they now speak with an original accent.

\section{An Analysis of Pound's Provençal Complex--His Imitation of the Troubadour Love Songs}

Pound had experimented with various poetic forms before he created modernist poems. His poems in the early stage can mirror the actual process of his development as a successful poet in the first decades of the 20th century. The case study presented in this part intends to reveal the shaping process of his poetry through the analyses of different types of poetic forms that he employed from the conventional ones to the modern ones. That is, the analyses start with his imitation of the Provencal troubadours and popular ballad, and then go to his understanding of the 19th-century Browning's Dramatic monologue and Yeatsian symbolist poem.

Pound's early poetry and translation are closely related to the Provençal lyrics. He had studied Latin and Greek in his university days, and later he translated some Greek love poems with Noel Stock and later he translated some Middle-Age troubadour love songs. Some of his translations of Greek poems are so marvelous that he was regarded as one of the important poet-translators of Greek lyrical poetry. His translations of Greek poems such as "Conversations in Courtship", "Pleasant Songs of the Sweetheart Who Meets You in the Fields" and "Garden Songs" are beautiful English versions. Nevertheless, it is his translation of Provençal love songs that reveals his talent as a translator and Romantic poet. In particular, through translating Cavacati's Latin poems, Pound summarized and put forward some valuable translation points that have been known as his important translation concepts and his theory of poetic language. The following sample poem "Na Audiart" (a troubadour love song) is characterized as colloquialism with some direct and passionate callings to the lover; more importantly in this translation, there remain some foreign words that make the English version be foreignizing. This translation mode has been a model for the successive translators and directly exercised influence on Francis Venuti who, on the basis of Pound's practice and theoretical concepts, put forward the translation concepts "foreignization" and "domestication". In translating this love song, Pound tried to imitate the original rhythmic structure and even the way by which the troubadour sang it. This device handling poetic rhythmic structure can be found in his later translation of "The Seafarer" and his later poems including The Cantos. In a sense, the imitation of the original rhythmic pattern is an important device of 
Pound translation techniques.

$\mathrm{Na}$ Audiart (a troubadour love song)

Que be-m vols mal/ Though thou well dost wish me ill

Audiart, Audiart,/ Where thy bodice laces start

As ivy fingers clutching through/ Its crevices,

Audiart, Audiart, Stately, tall and lovely tender

Who shall render/ Audiart. Audiart,

Praises meet unto thy fashion?/ Here a word kiss! /Pass I on

Unto Lady “Miels-de-ben,'/ Having praised thy girdle's scope

How the stays ply back from it;/ I breathe no hope

That thou shouldst.../Nay no whit

Bespeak thyself for anything./ Just a word in thy praise, girl,

Just for the swirl/ Thy satins make upon the stair,

'Cause never a flaw was there/ Where thy torse and limbs are met

Though thou hate me, read it set/ In rose and gold.

Or when the minstrel, tale half told,/ Shall burst to lilting at thy praise

“Audiart, Audiart".../ bertrans, master of his lays,'bertrans of Aultaforte thy praise

Sets forth, and though thou hate me well, / Yea though thou wish me ill,

Audiart, Audiart./ Thy loveliness is here writ till,

Audiart,/ Oh, till thou come again.

And being bent and wrinkled, in a form/ That hath no perfect limning, when the warm

Youth dew is cold/ Upon thy hands, and thy old soul

Scorning a new, wry'd casement,/ Churlish at seemed misplacement,

Finds the earth as bitter/ As now seems it sweet,

Being so young and fair/ As then only in dreams,

Being then young and wry'd,/ Broken of ancient pride,

Thou shalt then soften,/ Knowing, I know not how,

Thou wert once she/ Audiart, Audiart

For whose fairness once forgave/ Audiart,

Audiart/ Que be-m vols mal.

(Pound 2003: 26)

\section{An Analysis of Pound's Adoption of the Popular Ballad and His Improvement of the Poetic Form into the Literary Ballad}

Pound really experimented with various poetic forms in his early literary period. As a translator he ignored folk songs, but he had composed a few ballads and in his great book The Cantos, some lines are of ballad style. This is a significant connection between his early poetics and his late poetry.

Although ballad is not popular to the modernist poets like Pound, most of them did compose some ballades. Pound's ballads, in a sense, are popular, paralleling with his early best poems. It is because the characters of the ballade fit to Pound's poetic concepts--he has emphasized musical sense and simple language in a poem. Generally, every word of a ballad sprang in the first instance from the head of some individual, minstrel or peasant; just as every note, every phrase of a folk tune proceeded originally from the mouth of a solitary signer. By the 19th century new popular ballads had ceased to be composed orally, though variants of ballad stories proliferated. By the folk had been industrialized, mass literacy had been introduced, and primary oral composition was a thing of the past. People simply transferred it to the printed word. It was the literary men like Wordsworth and Pound who made the ballad a 
prestigious enough to be granted the status of hard covers in the course of time.

Comparatively, there are differences between the minstrel ballad, the popular ballad and the literary ballad. According to Alan Bold (1979),

The minstrel ballads are conspicuously different from the popular ballads. Whereas the popular ballads are impersonal, the minstrel ballads draw attention to the presence of the narrator who usually tells his audience to "listen". Whereas the traditional ballads rush into the narrative heart of the matter, the minstrel ballads display a leisurely approach to the story.

(1979: 10)

The modern conception of popular ballads is that the ballad is made for singing; it is a narrative song whose metrical structure conforms to the exigency of memorability. Because the popular ballads had an oral currency they had to be memorable, and all the stylistic features that can be associated with balladry. The simple rhymes, the incremental reputations, the obligatory epithets, the magical numbers, the nuncupative testaments, the commonplace phrases, the reliance on dialogue, the dramatic nature of the narrative: these make the ballad easier to remember, easier to memorize. The unique style of the ballads derived from its oral nature. But according to the rules of literary poetry, a poem should be written for the page, depends on the unexpected phrase, the ingenious rhyme, and the contrived figure of speech. Literary poets like to innovative; oral poets must depend on formulas. So the ballads written by literary poets do not rely on conventions and familiar structures, and they are not orally transmitted and transmuted.

Pound had experimented on both the popular ballad and the literary ballad. His ballads "Ballads of the goodly Fere" is a sample of conventional popular one, whereas his "A Villonaud: Ballad of the Gibbet" can be taken as a sample of modern literary ballad. In the former poem, Pound basically followed the principle of conventional popular ballad in the structure: a quatrain for each stanza and a similar rhyming scheme, but he did not copy the popular convention. So the poem does not contain sixteen stanzas (actually thirteen and half stanzas) and the rhyming scheme is not abab bcbc but loosely abcb dbeb.

\section{Ballad of the Goodly Fere}

Simon Zelotes speaking after the Crucifixion. Fere =Mate, Companion.

Ha' we lost the goodliest fere o' all/ For the priests and the gallows tree?

Aye lover he was of brawny men,/ O' ships and the open sea.

When they came wi' a host to take Our Man/ His smile was good to see,

"First let these go!" quo' our Goodly Fere,/ "Or I'll see ye damned," says he.

Aye he sent us out through the crossed high spears/ And the scorn of his laugh rang free,

"Why took ye not me when I walked about/ Alone in the town?" says he.

Oh we drank his "Hale" in the goos red wine/ When we last made company,

No capon priest was the Goodly Fere/ But a man o'men was he.

(Pound 2003: 109)

In the latter ballad, Pound emphasized the narrative character of a literary ballad that is different from the early popular ballad. It does not stick to the strict pattern of a French ballad with three stanzas linked by a refrain and rhyming ababbcbcC ( $\mathrm{C}$ being the refrain), or that of an Old English popular ballad that comprises sixteen stanzas and has the regular rhyming scheme ababbcbc.

\section{A Villonaud: Ballad of the Gibbet}

Or the song of the sixth companion

It being remembered that there were six of us with Master Villon, when that 
Expecting presently to be handed he writ a ballad whereof ye know:

"freres humains qui après nous vivez."

Drink ye a skoal for the gallows tree!

Francois and Margot and thee and me,

Drink we the comrades merrily

That said us, "till then" for the gallows tree!

Fat Pierre with the hook gauche-main,

Thomas Larron "Ear-the -less",

Tybalde and that armouress

Who gave this poignard its premier stain

Pinning the Guise that had been fain

To make him a mate of the "Haulte Noblesse"

And bade her be out with ill address

As a fool that mocketh his drue's disdeign.

Drink we a skoal for the gallows tree!

Francois and Margot and thee and me,

That hell breen not her o'er cruely.

Drink we the lusty robbers twain,

Black is the pitch o' their wedding dress,

Lips shrunk back for the wind's caress

As lips shrink back when we feel the strain

Of love that loveth in hell's disdeign,

And sense the teeth through the lips that press

'Gainst our lips for the soul's distress

That striveth to ours across the pain.

Drink we skoal to the gallows tree!

Francois and Margot and thee and me,

For Jehan and Raoul de Vallerie

Whose frames have the night and its winds in fee.

(Pound 2003: 29)

\section{An Analysis of "Cino", an Imitation of Browning's Dramatic Monologue}

"Cino" is one of Pound's popular dramatic monologues. Dramatic monologue is a particular poetic form initialed by Robert Browning. Pound was influenced by Robert Browning's creation in this period.

In this poem the character "I" expresses his worship of the ancient hero and beauty of human and nature. By singing highly of the ancient civilization of the society and of the beauty of man and nature, Pound expresses his complaints and criticism of the modern society in which various corruptions and dirties can be found everywhere.

The character "I" is a mask of Pound. During this period, he experimented with various poetic forms and narrative ways. The narrators of the poems in his early collections such as Personae and Exultations are masks of Pound who did not intend to express his views in direct ways and in person. Dramatic monologue is the most important one for him to develop his modernist poetry. He liked using this poetic form later in his modernist poems, including his masterpiece The Cantos.

Generally in a dramatic monologue, there is a dialogue between the speaker and the invisible listener. The language 
is simple and colloquial as a monologue in an ordinary play. This feature of poetic language can be found in his modernist poems and fit to his modernist poetic principles.

\section{Cino}

Italian Campagna 1309, the open road/ Bah! I have sung women in three cities,

But it is all the same;/ And I will sing of the sun.

Lips, words, and you snare them,/ Dreams, words, and they are as jewels,

Strange spells of old deity,/ Ravens, nights, allurement:

And they are not;/ Having become the souls of song.

Eyes, dreams, lips, and the night goes./ Being upon the road once more,

They are not./ Forgetful in their toweres of our tuneing

Once for wind-runeing/ They dream us-toward and

Sighing, say, "Would Cino,/ Passionate Cino, of the wrinkling eyes,

Gay Cino, of quick laughter, / Cino, of the dare, the jibe.

Frail Cino, strongest of his tribe/ That tramp old ways beneath the sun-light,

Would Cino of the Luth were here!"

(Pound 2003: 24)

\section{An Analysis of Pound's Yeatsian Symbolist Poem}

The relationship between Pound and Yeats is very particular. Here is more information about the relationship for the analysis of Pound's symbolist poem. As is known to most readers of modernist works, Pound contributed a lot to the second period of Yeats's poetic career, which begins with the poems of The Green Helmet in 1910. Among The Green Helmet and Other Poems, the poems best exemplifying Yeats's second period would be "No Second Troy", "Reconciliation", "Against Unworthy Praise", and "The Fascination of What's Difficult". According to Goodwin, "they are tightly-argued and passionate poems which nevertheless avoid the 'strong lines' and contorted syntax of the metaphysicals" (1966: 79). To take a close look at the poems of Yeats in this second period we have to examine the changes and variations of his styles. Those stylistic features include the complication of sentence-structure, the loosening and freeing of the iambic rhythm and the sparseness, directness and simplicity of Yeats's diction.

In the late 1880s and the 1890s Yeats held concurrently a "hard" and a "soft" view of the nature of poetry. However, by the time Yeats met Pound, he had rejected the "soft" view and confirmed his belief in the "hard". This can be demonstrated by the selection and treatment of the poems in The Green Helmet and Other Poems. The most definite influence of Pound on Yeats is that "he confirmed Yeats in the direction he was taking for the second period, and helped him, by suggestions about individual words and lines, to embody his theories more adequately in his verse" (Goodwin 1966: 85). What, then, is indicated by Yeats's record "I had a young man go over all my work with me to eliminate the abstract"? If the effects of this "going over" are virtually indiscernible in the revised version of the poems concerned, why does Yeats mention it? The answer is probably that one is taking too naïve a view of influence to expect Pound to have an effect on the actual construction or content of any particular poem. Yeats may have agreed with Pound that there was something wrong with many of his poems, but either Pound was not able to suggest specific emendations to correct the faults, or else Yeats felt that it was better to try to take account of the principles of Pound's objections in the writing of subsequent poems. If this were so, one would look not for specific verbal influence but rather for a general movement of Yeats's poems in the direction of Pound's principles. But such a movement could hardly be a very great one, for it has been shown that "Pound's and Yeats's principles were very similar at this time and that Pound considered Yeats to be putting his intentions fairly successfully into practice" (Goodwin 1966: 94).

Yeats ushered Pound into the London literary circle and encouraged him to study something new for the development of poetry. No doubt, Yeats's influence on Pound's early poetry is tremendous. Although Pound soon made his own way that was different Yeatsian Symbolism, he did write a few poems modeled on Yeats's Symbolism. Moreover, at 
the beginning of his stay in London, Pound ever read much symbolist works not only by Yeats and Swinburne, but also some of the main French symbolists such as Baudelaire, Verlaine, and Mallarmé.

\section{The White Stag}

I ha' seen them 'mid the clouds on the heather.

Lo! They pause not for love nor for sorrow,

Yet their eyes are as the eyes of a maid to her lover,

When the white hart breaks his cover

And the white wind breaks the morn.

(Pound 2003: 101)

This poem has some features of Yeats's Symbolism, that is, the language is simple and the symbols are definitely meaningful. This poem describes "the white hart" they were a hunting. The white hart may be the symbol of an energetic and brave pioneer who attracts all the admirers. Once it appears before them and presents his marvelous manner and spirit to them, the new world will be opened immediately--"When the white hart breaks his cover/And the white wind breaks the morn."

"The clouds on the heather", "white wind", "cover", and "morn" are symbols of the relevant things. The last two lines are also similar to Yeatsian symbols or Eliot's metaphysical metaphors. Actually symbolist device and metaphysical metaphor are of the same referential device. Obviously, it is different from imagist poem. Soon later, Pound gave up such an experiment and opened his own modernist way.

\section{Conclusion}

This paper presents the poetic conception of Ezra Pound--“A Few Don'ts”, trying to analyze the few important principles that Pound put forward in his early poetic conception, which set him apart from other poets before. In order to clarify the essence of Pound's early poetics, the paper has provide a detailed theoretical analysis of the basic imagist principles that Pound declared in his "A Few Don'ts" and also has given some detailed analyses of Pound's early poems. Each of them represents a different style or literary inheritance: "Cino" is the imitation of Robert Browning's dramatic monologue; "Na Audiart" is the troubadour love song; "Ballad of the Goodly Fere" belongs to the genre of ballad. Those early poems are Pound's powerful examples of his early poetics and his applications of his revolutionary thoughts on how poetry should be written in the new century. What Pound innovated in the poetry composition is of great importance if the new era wishes to shake off the banality and out-of-date tradition in literature. Pound changed a whole generation of poets and set a good example for those who desire to write in a new way.

\section{Acknowledgements}

The present research is sponsored by Beijing Higher Education Young Elite Teacher Project (YETP1507).

\section{References}

Abrams, M. H. (ed.). (1986). The Norton Anthology of English Literature. New York: W. W. Norton\& Company.

Amdur, A. S. (1936). The Poetry of Ezra Pound. America: Harvard University Press.

Bold, Alan. (1979). The Ballad. London: Methuen \& Co. Ltd.

Goodwin, K. L. (1966). The Influence of Ezra Pound. London: Oxford University Press.

Pound, Ezra. (2003). Poems and Translations. New York: Literary Classics of United States, Inc., NY. 